Article

\title{
Determinants of CSR Application in the Hotel Industry of the Colombian Caribbean
}

\author{
David Daniel Peña-Miranda ${ }^{1, *}$, Jesús Arteaga-Ortiz ${ }^{2} \mathbb{D}$ and José Ramón-Cardona ${ }^{3} \mathbb{C}$ \\ 1 Faculty of Business and Economic Sciences, University of Magdalena, Carrera 32 No. 22-08, \\ Santa Marta 470004, Colombia \\ 2 Faculty of Economics, Business and Tourism Studies, Campus Universitario de Tafira, University of Las \\ Palmas of Gran Canaria, Juan de Quesada, 30, 35001 Las Palmas de Gran Canaria, Spain; \\ jesus.arteaga@ulpgc.es \\ 3 Tourism University School of the Consell of Ibiza, University of the Balearic Islands, C/Bes, No 9, \\ 07800 Ibiza, Spain; jose.ramon@uib.es \\ * Correspondence: ddpena@unimagdalena.edu.co; Tel.: +57-3012516006
}

Received: 13 July 2019; Accepted: 27 August 2019; Published: 16 September 2019

\begin{abstract}
This study identifies the determinants of corporate social responsibility (CSR) application in the hotel industry of the Colombian Caribbean. A structured CSR questionnaire was applied to a sample of 224 hotels and multivariate statistical analysis was carried out with the support of the DYANE software. The findings suggest that the degree of CSR application is influenced by the size, age, category, type of contract, financial performance, and level of investment in innovation of the establishments; as well as by the sex, age, level of education, and degree of the directors' autonomy in CSR-related decision-making and their motivations and perceived obstacles. This study on CSR is one of the first that has been applied in the hotel industry of the Colombian Caribbean and the results have important theoretical and practical implications to academia and the hospitality industry. Businessmen have valuable information to improve the levels of CSR in their companies and therefore contribute to a more responsible and sustainable tourism development in the Colombian Caribbean. Future research should include other variables like the type of corporate governance and the risk appetite of the decision-making body of the hotel and the social responsibility of all the stakeholders implicated in the destination.
\end{abstract}

Keywords: corporate social responsibility; application of CSR; tourism; hotel industry; Colombian Caribbean

\section{Introduction}

Corporate social responsibility (CSR) has activated the imagination and attracted the interest of many stakeholders, including the private sector, civil society, public sector organizations, academics, the public in general, among others [1]. The role of CSR has been enhanced given the attention it has received from large consulting firms such as KPMG International, which since 1993 has been conducting the KPMG survey of corporate responsibility reporting, noting that in its latest report it has included 4900 companies in 49 countries and regions, making the most extensive survey ever [2].

This study demonstrates the importance that companies give to CSR through reporting. According to [2], most of the world's biggest companies now integrate financial and non-financial data in their annual financial reports and issues like human rights, carbon emissions, climate-related financial risk, and United Nations Sustainable Development Goals (SDGs), are increasingly relevant in the business agenda.

In the academic world, research in this topic has flourished in recent decades, however, in the real world, little is known about culture, interactions, and in particular, the practices that shape 
CSR [3]. Also, it is a well-known fact that companies are currently incorporating CSR in their own way, given that the demands of a changing environment have led firms to pay increasing attention to their influence on this environment, in economic, social, and environmental terms [4].

In this respect, and to clarify the concept, it can be said that one of the most widely accepted definitions in the scientific literature on CSR is the one proposed by [5], who assumes CSR as a concrete response from firms to the demands or expectations of society. This implies that company directors must, of course, behave ethically and contribute to the development of the economy, but they must also promote a better quality of life for their employees, their families, and the local communities [6].

Governments, consumers, employees, suppliers, and many other groups have molded the CSR concept through their expectations that companies would act responsibly when conducting their operations, given that CSR is based on the idea that companies do not have a solely financial purpose but rather, a set of three basic imperatives (economic, social, and environmental,) that guide their decisions and activities, and that are all equally valid and necessary within the companies [7].

Reference [8] Reinforces this idea by affirming that CSR involves bringing company behavior to a level that is congruent with the norms, social values, and the expectations that prevail at any given moment. In the same line, Reference [9] argued that the geographic space and time are variables that directly affect the forms and content of CSR; Reference [10] similarly set out that the understanding and application of CSR varies according to the locality and the industry, thus, the success of this application is based on the specific sector and the environmental conditions facing each of the companies that make up this sector at any given time.

Given the above, in order to correctly understand CSR and its application, it is indispensable to carry out sectorial studies. In this respect, in the tourism industry, the characteristics of CSR are different to those presented in other sectors [11]. According to [12], the socially responsible behavior of companies in the tourism sector has been receiving more attention through the media and its CSR programs are closely related to the corporate initiatives taking place around the world.

It is interesting to carry out a detailed analysis of CSR within the field of tourism, since it is one of the most important sectors for the global economy, considered key to development, prosperity, and well-being, given its real potential for socioeconomic progress, both in developed and developing countries. In tourism, the hotel industry is one of the most representative, however, despite the large amount of research conducted on CSR and the fact that large hotel chains have moved towards more responsible corporate behavior, CSR studies focused on the tourism and hotel sector are relatively scarce [13] and even more so in developing countries [14].

Specifically, compared to other sectors, the tourism and hospitality literature on CSR is scarce [15], but there has been an important growth in the last decade, specifically in the last 5 years with more than $70 \%$ of articles published of that period [16] and in the practice, gradually, CSR has become a concern for many companies in the tourism industry [17]. In this sense, conducting studies on CSR in tourism and hospitality is an important challenge and a great contribution to advancing knowledge in the topic.

As such, the central aim of this work was to carry out a theoretical reflection, followed by a practical study that enables the identification of the determinant factors for the application of CSR in tourism by carrying out quantitative research that is consistent in the application of a structured CSR questionnaire to hotel companies in the Colombian Caribbean, followed by multivariate statistical analysis for quantitative data, to understand and interpret the results and everything they mean in terms of the implications, limitations, and future lines of research. It is interesting to say that previous studies have analyzed variables related to the size, age, and category of the companies (in this case, hotels) and the sex, age, and level of education of the director, but none of them carry out a full analysis involving all of these relations, and this is a real contribution of this research.

These issues are developed throughout the rest of the document, which have been divided into four parts that in synthesis consists of an extensive literature review, the methodology used, the results found, and the main conclusions of the study. 


\section{Theoretical Background}

This section describes the most widely accepted theories in the CSR literature, relevant studies on the topic applied to the tourism sector and hotel industry, and finally the theoretical framework that supports the main topic of this study, that is, the determinants of CSR application.

\subsection{CSR Theories}

Many studies attempt to identify CSR theories [18-22]. In this respect, the work of the latter stands out as one of the most widely accepted in scientific literature when classifying the CSR theories into four groups, related to the benefits (instrumental theories), political action (political theories), social demands (integrative theories), and ethical values (ethical theories).

According to [22], in the instrumental theories, the company is seen exclusively as a means to create wealth. On the other hand, political theories emphasize the social power that the company requires as it inserts itself into society. In the integrative theories, the company focuses on the identification and response to social demands such as compliance with the law, public policies, and a balanced management of the stakeholders.

Finally, the ethical theories are based on the company activities that respond to compliance with universal rights, such as human rights, labor rights, respect for the environment, and a concern for society's sustainable development.

Bearing this in mind, the present study is identified with ethical theories, since CSR, in the first place, is an ethical concept [23] that in a broad sense leads to sustainability. In this sense, companies that base their CSR on ethical theories, seek to do the right thing and contribute to the common good through the implementation of four subcategories of the ethical theories: the normative stakeholder theory; the universal rights; the sustainable development; and the common good approach [24-27]. In this respect, among the subcategories of the ethical theories, this study used the sustainable development that consists in trying to achieve, in a balanced manner, the economic development, the social development, and the environmental protection [28].

It is important to mention here that beginning at the company management level there is a direct relationship between the director's profile-measured by the perceived role of ethics-and social responsibility [29]. Considering this, the present research applies the sustainable development based on ethical theory, on the one hand, because the fieldwork was carried out directly on the company directors, and, on the other, due to the study sector is tourism and in this sense, the World Tourism Organization (UNWTO) has emphasized the need to promote responsible and sustainable tourism that benefits all sectors of society [30].

As evidence of the above mentioned, this agency also proclaimed in the General Assembly of 1 October 1999 in Santiago de Chile, the principles of the Global Code of Ethics for Tourism [31] as a fundamental framework of reference for responsible and sustainable tourism around the world and this code was recognized by the United Nations General Assembly through resolution A/RES/56/212 of 21 December 2001.

\subsection{CSR in the Tourism Sector and Hotel Industry}

Authors such [32] and [12] have shed light on the little existing research on CSR, from a holistic point of view, in the field of tourism and, more specifically, the hotel industry. However, it is important to mention that, in 2011, Professor Christine Lynn, Director of Isbell Hospitality Ethics at the School of Hotel and Restaurant Management (Northern Arizona University) carried out one of the most comprehensive and systematic literature reviews on CSR in tourism from a broad perspective of its ethical nature.

This study indicates that in 20 years, 527 articles have been written which have been grouped into 12 categories. Unethical actions (93); how ethical are we? (49); how to do the right thing? (79); company values (17); ethics and leadership (17), codes of ethics, what is needed and how to develop them? (75); 
ethics for educators in tourism (5); teaching ethics (38); the ethics of tourism (60); trends, problems and challenges (24); corporate responsibility (38); and green/sustainable practices (32). Of this group, we analyzed four categories which have the most influence on CSR and found that only 67 articles were published in science reviews, as follows: 21 on codes of ethics, 36 on ethics and tourism, 5 on corporate responsibility, and 5 on green/sustainable practices. This indicates that, on average, a little over three articles per year were published, a low data for a topic as relevant as CSR, in one of the most important economic sectors, tourism.

As well as studies, it is important to mention the conclusions of five important academic works carried out by [33-36] and [16].

Reference [33], in their study, argued that the literature on CSR related to the travel and tourism industry has been increasing, given its close conceptual relationship with sustainability. However, the empirical data on the perceptions and actions of this industry in relation to CSR continues to be scarce. Reference [34] concluded that studies have focused on three macrolevels which are implementation, the economic rationale for acting more responsibly, and the social relations of CSR; for these authors the interest in CSR as an approach to tourism management and management is growing and they recommend to progress in research a greater critical engagement with mainstream thinking on CSR, as well as a better conceptual and methodological sophistication. The study of [35] is a literature review which reveals information on the advances of the sustainable tourism agenda, through a CSR perspective in the sector, concluding that there are continuous discussions in many international forums, conferences, seminars, and symposia on sustainable tourism, responsible behavior, and related topics. But these are characterized by the presence of theories that define the concepts, rather than being practical workshops that identify the business model and the way in which we should activate a more protagonist participation of CSR in the tourism industry.

Reference [36] reveal two gaps: a theoretical one between the lack of critical commitments to the conceptualization, and another that is contextual and refers to the application of CSR. To deal with this, they suggest that research into CSR must fundamentally debate the relevance and application of CSR in the sector and its relationship with the external stakeholders, before trying to measure its internal benefits and financial impact. Finally, Reference [16] conclude that greater attention has been given to research on certain stakeholder groups such as management, employees, shareholders, and consumers, giving less emphasis to other important stakeholders like communities, ecosystems, suppliers, Non-governmental organizations, and government. In this sense, they argue that tourism and hospitality firms have important opportunities to document and engage the external stakeholders mainly in the journey towards corporate sustainability and responsibility.

For the hotel industry, an interesting study was made by [37] who carried out a literature review for the 2004-2014 period, in which they found 52 studies that group four broad lines of research that describe the relationship of CSR with practices, accountability, marketing, and corporate financial performance. The authors shed light on the scarcity of works found, as 52 articles, in the period studied, can be considered very few for a subject as important-today-as CSR, and even more so in a sector such as the hotel industry, which is more relevant than the tourism sector, still considered one of the most important economic sectors in the world, and is something that has been mentioned throughout this article.

The above was recently corroborated by [13], when they updated a previous study with a literature review in the same sector during the 2006-2015 period whose results have been published in the prestigious science journal Cornell Hospitality Quarterly. The authors found 48 studies grouped into three research lines: CSR practices, CSR report, and CSR impacts. The latter has been divided into two research sub lines: one from the consumers' perspective (marketing) and the other from the companies' perspective (company performance). The main conclusions state that the practices and impacts have received the greatest attention. Consumer reactions to CSR and the link between CSR and corporate financial performance continue to present important gaps with respect to research into the topic in the 
hotel industry. The authors also highlight that a key actor for CSR in hotels: the local community has been subject to very little research.

They also mention the ratified scarcity of studies on CSR in the hotel industry and they recommend that research should focus in consumer reactions and awareness of CSR; the stakeholder's-the local community, particularly-perception, and reaction to CSR; customer willingness to pay a price premium for hotels that implement CSR strategies; the link between CSR and corporate financial performance; and finally, the possible relationship between CSR and firm value in a broad sense, not only in the financial one.

\subsection{Determinants of CSR Application}

The literature on the application of CSR has focused mainly on the description and theorization of ideal processes, structures, and considerations that have similar components including the evaluation of CSR, the creation of a CSR strategy, the identification of the specific commitments that must be made, the creation of supervision and reporting systems, the identification of appropriate communication channels for the different publics, and the regular review of firm performance [38]. That said, regarding the determinants of CSR application, different studies have shown certain links between the degree of CSR application and several variables related to the company (size, age, category) and the director (sex, age, and level of education), but none of them carry out a full analysis involving all of these relations, and this is precisely the main motivation and contribution of the approach proposed.

Insofar as the size variable, we found that a variety of research has concluded that in the larger companies, the level of CSR practices is higher [39-41]. Likewise, several studies have concluded that there is a positive relationship between the age variable (time in operation) at the hotel and the degree of implementation of CSR activities [41,42]. In relation to the director variable, we found that characteristics such as sex, age, and level of education influence the degree of CSR application [41,43-49].

Similarly, Reference [50] and [51] suggested in their studies that women directors tend to apply more CSR activities in their companies. Age is another important determinant to knowledge, attitudes, values, and behavior in this regard [52,53]. For example, younger directors are more likely to apply CSR practices [43]. Level of education (primary, secondary, university undergraduate, university graduate) has also been fundamental in understanding the knowledge and behavior of directors with regards the implementation of CSR activities [53,54].

Motivation and obstacles to the application of CSR tend to be internal in nature (endogenous) and external (exogenous) to the organization and they were identified based on studies on economic sectors in general [39,55], of the tourism sector in general [33], and the hotel industry in particular [41,56]. The most frequently cited internal motivations are related to the reflection of moral and ethical values of the director and in the external sphere, the improvement of image, reputation, and customer loyalty. The most frequently cited internal obstacle is related to a lack of money and time, and in the external sphere with the pressure of competition that obliges companies to minimize costs as these do not apply CSR measures.

In addition, based on the experience of researchers on the topic and previous exploratory studies carried out in the region $[57,58]$, as a novel concept and to generate greater corporate implications based on the research, the variables contract, financial performance, and the hotel's level of investment in innovation were included, as were the degree of the director's autonomy in CSR-related decision-making.

In this respect, in order to contribute to the literature and to study the effects of these variables in an integral way, the research hypotheses set out for this study is as follows:

Hypothesis 1 (H1). The degree of application of CSR activities is influenced by the size, age, category, type of contract, financial performance, and level of investment in innovation of the hotel. 
Hypothesis 2 (H2). The degree of application of CSR activities is influenced by the sex, age, and level of education of the director, his or her autonomy in CSR-related decision-making, and his or her perceived motivations and obstacles.

In sum, the degree of CSR application has been measured based on the economic activities (ECA), social activities (SOA), and environmental activities (ENA) that the company carries out which were proposed, bearing in mind the studies on CSR globally [59], in Latin America [60], in Colombia [61], on the tourism sector in general $[33,62]$ and the hotel industry in particular $[41,63-68]$. It is relevant to say that this is an important theoretical contribution of the study (see Table 1).

Table 1. Classification of corporate social responsibility (CSR) activities by dimension.

\begin{tabular}{|c|c|c|}
\hline Economic Activities (ECA) & Social Activities (SOA) & Environmental Activities (ENA) \\
\hline $\begin{array}{l}\text { ECA1. CSR is integrated into the } \\
\text { strategy of my business (mission, vision, } \\
\text { values, policy, strategic plan). } \\
\text { ECA. We are part of an international, } \\
\text { national, regional, or local CSR initiative } \\
\text { (Global Compact, Code of Ethics for } \\
\text { Tourism, GRI, and other national, } \\
\text { regional or local ones). } \\
\text { ECA3. We concern ourselves with } \\
\text { providing high quality products and/or } \\
\text { services at competitive prices (good } \\
\text { value for money). } \\
\text { ECA4. We know the needs, expectations, } \\
\text { and satisfaction of our clients. } \\
\text { ECA5. We give our clients complete, } \\
\text { transparent, and honest information } \\
\text { about the commercial offer, and we } \\
\text { respect their rights. } \\
\text { ECA6. We encourage our clients to use } \\
\text { and consume local products during their } \\
\text { stay (the tourism business value chain). } \\
\text { ECA7. We hire local personnel at } \\
\text { different hierarchical levels of } \\
\text { responsibility in the company } \\
\text { (low-medium-high). } \\
\text { ECA8. We pay a dignified and just } \\
\text { salary to our workers, which, at the very } \\
\text { least, complies by existing legislation } \\
\text { and the sector's market prices. } \\
\text { ECA9. We hire local suppliers. } \\
\text { ECA10. We introduce aspects of social } \\
\text { responsibility in our purchasing criteria. }\end{array}$ & 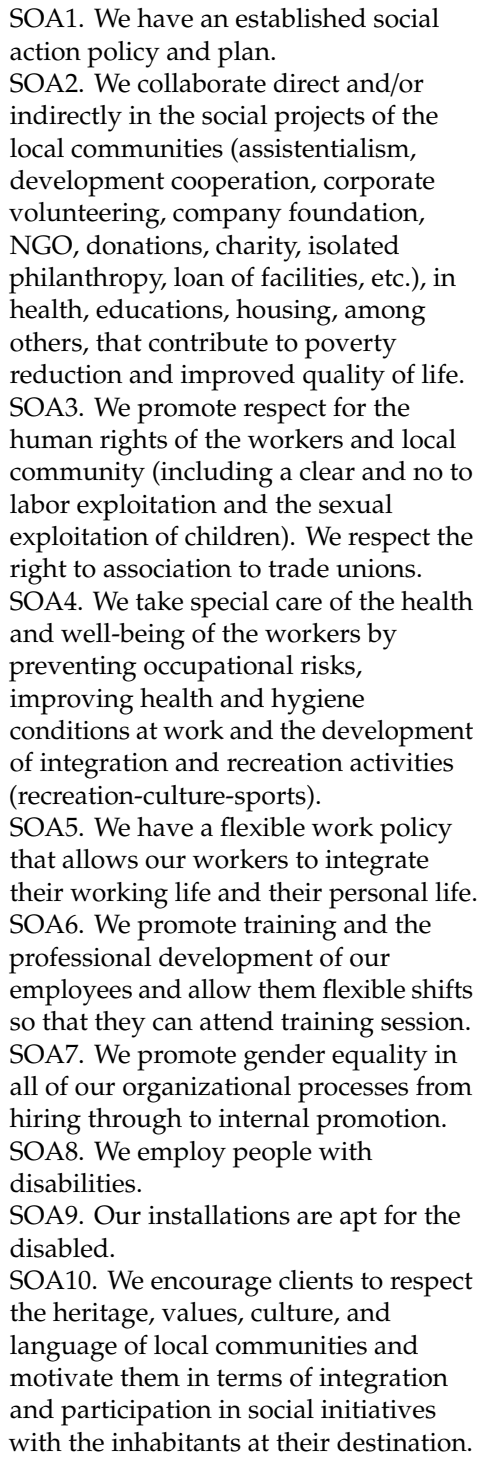 & $\begin{array}{l}\text { ENA1. We have an established } \\
\text { environmental plan and policy. } \\
\text { ENA2. We have a concrete strategy to deal } \\
\text { with global warming (climate change). } \\
\text { ENA3. We have an environmental } \\
\text { certificate or we are in the process of } \\
\text { obtaining one. } \\
\text { ENA4. We have identified our } \\
\text { environmental impact and have } \\
\text { implemented concrete actions to } \\
\text { minimize it. } \\
\text { ENA5. We have energy, water, and paper } \\
\text { saving strategies (employees-clients). } \\
\text { ENA6. We use some kind of energy } \\
\text { alternative (renewable: solar, wind, ocean, } \\
\text { geothermal, biomass or hydraulic). } \\
\text { ENA7. We have programs or systems for } \\
\text { waste reduction, recycling, separation } \\
\text { or treatment. } \\
\text { ENA8. We introduce environmental } \\
\text { aspects in our purchase criteria and in the } \\
\text { selection of our suppliers and commercial } \\
\text { partners (tourism business value chain). } \\
\text { ENA9. We encourage our clients to care for } \\
\text { and protect the environment at } \\
\text { their destination. } \\
\text { ENA10. We carry out awareness raising } \\
\text { campaigns and/or environmental training } \\
\text { for employees, clients, commercial and/or } \\
\text { local communities (the tourism business } \\
\text { value chain). }\end{array}$ \\
\hline
\end{tabular}

For practical purposes, ECA, SOA, and ENA carry the same importance in fulfillment of the theory of sustainable development based on ethics, in the sense of promoting corporate actions developed within a framework of integrated economic, social, and environmental development that insures a balance between company profits, the environment, and society. 
It is important to mention that this list of activities was reflected in a questionnaire (as explained in the next session), whose design took into account the contributions found in the scientific literature which were mentioned previously in this item and additionally the general recommendations regarding the form, order and writing of questions of [69]. In summary, the final questionnaire consists of 82 questions distributed as follows; 23 questions about general issues of the hotel and its director; 7 questions related to the knowledge that directors have about CSR; 43 issues related to the CSR practices of hotel establishments; and 9 questions to measure their CSR communication. For this paper, were taken into account the answers to the questions related to the general issues of the hotel (size, age, category, type of contract, financial performance, level of investment in innovation, etc.) and its director (sex, age, level of education, etc.) and also those related to CSR practices (ECA, SOA, and ENA activities) detailed in the Table 1.

\section{Methodological Approach}

First, we carried out a scientific literature review which, in practice, was a study on relevant CSR publications focusing on their application and then based on a synergy between the research studies found, the experience of the researchers of this work on CSR, and previous exploratory studies carried out in the region $[57,58]$ the following objective was raised: identify the determinants of the CSR application in the hotel industry in the Colombian Caribbean.

Following this, we carried out the respective empirical study, which consisted in the definition, classification, and measurement of the variables, using a structured questionnaire in CSR that was answered by a sample of hotel directors. The questionnaire used for this study consisted of several groups of questions, about the hotel, the director, the CSR applications, and the motivations and obstacles for its application. All these questions were elaborated based on the literature consulted. Formal recommendations [69] and previous qualitative works [57,58] were taken into account. Finally, several pre-tests were conducted with hotel directors and academics. It should be noted that the reliability and validity analyses of the scales had not previously been performed with these specific scales and that is the reason for conducting a principal components analysis before proceeding to multiple linear regressions.

In relation to the hotel, the response options have been taken into account (in brackets): size (less than 10 employees; 10-50 employees; 51-200 employees; more than 200 employees); seniority (less than 10 years; 10-20 years; 21-40 years; more than 40 years); category (none; 1 -star; 2 -stars; 3 -stars; 4-stars; 5-stars; other); type of management (owner; franchise; lease; management); financial situation (bad; regular; good); degree of indebtedness (bad; regular; good); and level of investment in innovation (bad; regular; good).

In relation to the director, the response options have been taken into account (in brackets): sex (man; woman); age (less than 40 years, 44-60 years; more than 60 years); education level (primary; secondary; graduate studies; postgraduate studies); and CSR decision capacity (measured on a 5-point Likert scale).

To measure CSR applications, the activities listed in Table 1 were used in the form of three scales (ECA, SOA, and ENA), based on the literature [33,41,59-68]. The response to these items was based on a six-point Likert scale, 1 being "null" and 6 "maximum."

In addition, a scale was used to measure "motivations" (MOT1 values/management style; MOT2 competitiveness; MOT3 image/reputation; MOT4 stakeholders pressure) and another to measure "obstacles" (OBS1 attitude/direction style; OBS2 ignorance; OBS3 absence resources; OBS4 absence government support), based on the literature. The response to the items was based on a five-point Likert scale, with 1 "total disagreement" and 5 "total agreement."

The population under study involved hotels in the Colombian Caribbean (Barranquilla, Santa Marta and Cartagena, as the main cities) and the most important statistical information is shown in Table 2. For the preparation of the sample, the National Tourism Registry was used. According to this Registry, there were 506 hotels in the cities of Barranquilla (116), Santa Marta (168), and Cartagena 
(222). The sample needed to have a sampling error of $5 \%$ was 224 hotels. The selection of the 224 hotels was carried out by a non-probabilistic sampling for convenience (hotels affiliated with COTELCO and snowball sampling) and trying to maintain the proportions by cities. Of the total sample (224 hotels), 58 are located in Barranquilla (25.90\%), 72 and Santa Marta (32.14\%), and 94 in Cartagena (41.96\%). This is almost the same proportion of the hotels per city with respect to the total population N (506), which guarantees its representativeness. The contact details were obtained from the National Tourism Registry and the hotel directors were contacted in two ways: The questionnaire was sent by email and returned in the same way; in addition, the directors were contacted by phone and also some were visited in person at their hotels, as a reminder and to encourage them to participate in the survey. Through this triple form of contact, a high response rate was achieved, avoiding the sample error due to non-response. A total of 222 hotels (that is, $99.1 \%$ of the selected sample) answered the questionnaire in a valid way, obtaining a representative sample of the target population and without significant biases.

Table 2. Datasheet for the fieldwork.

\begin{tabular}{ll}
\hline Population: & 506 Hotels \\
Geographical area: & Colombian Caribbean (Barranquilla, Santa Marta and Cartagena) \\
Confidence interval, error and proportions (p and q) & $95.5 \%-5 \%$ con $\mathrm{p}=\mathrm{q}=0.5$ \\
pre-established to calculate sample size: & 224 hotels \\
Sample size: & Hotel \\
Sample units: & Director \\
Survey: & $99 \%-11 \%$ (222 hotels) \\
Response rate: & $95.5 \%-0.64 \%$ con $\mathrm{p}=\mathrm{q}=0.5$ \\
Sampling error obtained based on the response rate with a & \\
confidence interval and pre-established proportions (p and $\mathrm{q}):$ & \\
\hline
\end{tabular}

Source: Authors.

Finally, after gathering the information, using the computer program-design and analysis of surveys DYANE version 4, it proceeded to analyze the data and interpret the results, with a reasoning process supported by multivariate statistical analysis for quantitative data applying principal components analysis (henceforth PCA) and multiple linear regression.

PCA is a technique commonly used to verify the validity of a measurement scale or if it is better to separate it into several scales. All this is supported by various reliability and validity tests, such as Barlett Test, Cronbach's Alpha, factorial load, or commonality. The scales resulting from the application of PCA (items with high loads in the same factor) can already be used in multivariable analysis of different types with reasonable guarantees of reliability and validity. In addition, the PCA reduces the items initially proposed and measured by Likert-type scales to factors (numerical variables) with a normal distribution that can be easily used as dependent or independent variable in various types of regressions. In this work, the PCA is the first phase of analysis and allows converting "CSR applications", "motivations", and "obstacles" into a smaller number of numerical variables. In addition, there is a verification of the Table 1 scales.

To determine which characteristics of the hotel or the hotel director have a significant effect on the application of CSR activities, five multiple linear regressions were made (one for each factor resulting from the PCA on the three types of CSR activities). In this case, linear regression is the most correct analysis because regression-dependent variables are numerical, thanks to the application of the PCA. In the independent ones there are several numerical variables (motivations, obstacles, CSR decision capacity) and a set of dummy variables resulting from transforming the categorical answers. For each dependent variable, a first multiple linear regression was carried out with all the independent variables raised (motivations, obstacles, characteristics of the hotel, characteristics of the director) and a second regression keeping only the independent variables with a minimum level of significance of 0.1 , the latter being those that appear in the results section (in order to reduce the number of tables). 


\section{Results}

Below are the results of the analysis of the application of two multivariate analysis techniques: PCA and multiple linear regression.

\subsection{PCA of the Study Variables}

In order to reduce the dimension of the number of variables (independent and dependent) that have been considered with the analysis of the degree of CSR application and to facilitate the interpretation of the data with the least possible information loss, five PCAs were carried out (homoscedasticity verified with Bartlett's test): three corresponded to the dependent variable (one for each group of activities: economic, social and environmental), and two to the independent variables related to the motivations and obstacles for the implementation of CSR practices.

The PCA of the economic activities evinces the existence of two main factors that together explain $77.39 \%$ of the variants of the 10 original variables (Table 3). Factor 1 is associated to the activities aimed at the market and the competitiveness of the hotel; thus, this factor can be identified as ECA market/competitiveness. Factor 2 is associated to the activities aimed at the CSR strategy and can be identified as ECA strategy CSR. The Bartlett test rejects the null hypothesis of non-significant correlation, meaning that the application of PCA to the variables analyzed is adequate. Also, the Cronbach alpha coefficient (Factor 1: 0.942 and Factor 2: 0.874) revealed high reliability on the scale variables that make up each factor.

Table 3. PCA (Principal Components Analysis) of the economic activities (ECA).

\begin{tabular}{cccc}
\hline Variables & Factor 1 & Factor 2 & Communality \\
\hline ECA1_CSR & 0.318 & $0.840^{*}$ & 0.806 \\
ECA2_CSR & 0.183 & $0.876^{*}$ & 0.801 \\
ECA3_CSR & $0.868^{*}$ & 0.078 & 0.759 \\
ECA4_CSR & $0.848^{*}$ & 0.234 & 0.773 \\
ECA5_CSR & $0.809^{*}$ & 0.155 & 0.678 \\
ECA6_CSR & $0.767^{*}$ & 0.468 & 0.808 \\
ECA7_CSR & $0.762^{*}$ & 0.438 & 0.772 \\
ECA8_CSR & $0.829 *$ & 0.370 & 0.823 \\
ECA9_CSR & $0.757^{*}$ & 0.437 & 0.764 \\
ECA10_CSR & 0.233 & $0.838^{*}$ & 0.756 \\
Own Value & 4.742 & 2.997 & \\
Variance & $47.42 \%$ & $29.97 \%$ & \\
Accumulated & $63.69 \%$ & $77.39 \%$ & \\
\hline
\end{tabular}

${ }^{*}$ Loads (with good values) of retained factors after varimax rotation.

The PCA of the social activities shows that two main factors can explain $70.92 \%$ of the variance of the 10 original variables (Table 4 ). Factor 1 , is associated to the activities that target work conditions and respect for the local community, and can be identified as SOA work conditions and respect for the local community. Factor 2 is associated to activities aimed at policy, and the social and disability plan and can be identified as SOA policy, social action and disability plan. The Bartlett test rejects the null hypothesis of non-significant correlation, meaning that the application of PCA to the variables analyzed is adequate. Also, the Cronbach alpha coefficient (Factor 1: 0.929 and Factor 2: 0.826) revealed high reliability on the scale of variables that make up each of the factors. 
Table 4. PCA of the social activities (SOA).

\begin{tabular}{cccc}
\hline Variables & Factor 1 & Factor 2 & Communality \\
\hline SOA1_CSR & 0.414 & $0.682^{*}$ & 0.637 \\
SOA2_CSR & 0.521 & $0.686^{*}$ & 0.742 \\
SOA3_CSR & $0.577^{*}$ & 0.034 & 0.334 \\
SOA4_CSR & $0.812^{*}$ & 0.388 & 0.809 \\
SOA5_CSR & $0.807^{*}$ & 0.457 & 0.860 \\
SOA6_CSR & $0.808^{*}$ & 0.440 & 0.847 \\
SOA7_CSR & $0.800^{*}$ & 0.184 & 0.674 \\
SOA8_CSR & 0.049 & $0.841 *$ & 0.709 \\
SOA9_CSR & 0.257 & $0.840 *$ & 0.770 \\
SOA10_CSR & $0.620 *$ & 0.569 & 0.708 \\
Own Value & 3.833 & 3.259 & \\
Variance & $38.33 \%$ & $32.59 \%$ & \\
Accumulated & $60.18 \%$ & $70.92 \%$ & \\
\hline
\end{tabular}

* Factorial loads (with good values) after varimax rotation.

The PCA of the environmental activities reveals the existence of a principal factor that explains $73.32 \%$ of the variance of the ten original variables (Table 5) and as it is associated to the activities targeting the environment it has been identified as ENA environmental activities. The Bartlett test rejects the null hypothesis of non-significant correlation, meaning that the application of PCA to the variables analyzed is adequate. Also, the Cronbach alpha coefficient (0.955) revealed high reliability on the scale of variables that make up each of the factor.

Table 5. PCA of the environmental activities (ENA).

\begin{tabular}{ccc}
\hline Variables & Factor 1 & Communality \\
\hline ENA1_CSR & $0.926^{*}$ & 0.857 \\
ENA2_CSR & $0.899^{*}$ & 0.808 \\
ENA3_CSR & $0.893^{*}$ & 0.797 \\
ENA4_CSR & $0.923^{*}$ & 0.852 \\
ENA5_CSR & $0.880^{*}$ & 0.774 \\
ENA6_CSR & $0.453^{*}$ & 0.206 \\
ENA7_CSR & $0.891^{*}$ & 0.795 \\
ENA8_CSR & $0.810^{*}$ & 0.655 \\
ENA9_CSR & $0.880^{*}$ & 0.775 \\
ENA10_CSR & $0.903^{*}$ & 0.815 \\
Own Value & 7.332 & \\
Variance & $73.32 \%$ & \\
Accumulated & $73.32 \%$ & \\
\hline
\end{tabular}

* Factorial loads (with good values) after varimax rotation

The PCA carried out for motivations (Table 6) and obstacles (Table 7) shows that there is a principal factor for each. In the first case, the principal factor explains $69.07 \%$ of the variance of the four original variables and is associated to the motivations relating to each of those variables-values and management style, competitiveness and hotel image, and stakeholder pressure- thus, this factor can be identified as motivations MCISP. In the second case, the principal factor explains $62.96 \%$ of the variance of the four original variables and is associated to the obstacles relating to each of those variables, that is attitude and management style, lack of knowledge and absence of resources (financial, time and human), and government support. This factor is identified as Obstacles MLKRG. 
Table 6. PCA of the motivations.

\begin{tabular}{ccc}
\hline Variables & Factor 1 & Communality \\
\hline MOT1_CSR & $0.618^{*}$ & 0.382 \\
MOT2_CSR & $0.934^{*}$ & 0.873 \\
MOT3_CSR & $0.948^{*}$ & 0.899 \\
MOT4_CSR & $0.781^{*}$ & 0.610 \\
Own Value & 2.763 & \\
Variance & $69.07 \%$ & \\
Accumulated & $69.07 \%$ & \\
\hline
\end{tabular}

* Factorial loads (with good values) after varimax rotation.

Table 7. PCA of the obstacles.

\begin{tabular}{ccc}
\hline Variables & Factor 1 & Communality \\
\hline OBS1_CSR & $0.823 *$ & 0.678 \\
OBS2_CSR & $0.940 *$ & 0.883 \\
OBS3_CSR & $0.884 *$ & 0.780 \\
OBS4_CSR & $0.419 *$ & 0.176 \\
Own Value & 2.519 & \\
Variance & $62.96 \%$ & \\
Accumulated & $62.96 \%$ & \\
\hline * Factorial loads (with good values) after varimax rotation.
\end{tabular}

In both cases, the Bartlett test rejects the null hypothesis of non-significant correlation, meaning that the application of PCA to the variables analyzed is adequate. Also, the Cronbach alpha coefficient revealed high reliability on the scale of variables that make up each of the factors in the two analyses, obtaining values of 0.783 (motivations), and 0.799 (obstacles).

\subsection{The Study's Multiple Linear Regressions}

Based on the results for the item above, we carried out five multiple linear regressions that explain the relations between the dependent variable: degree of CSR application (converted into ECA market/competitiveness; ECA estrategy CSR; SOA work conditions and respect for the local community; SOA policy, social action and disability plan; and ENA environmental activities) and the independent variables (explanatory or predictive) proposed in the study and that are related to the hotel characteristics (size, age, category, type of contract, financial performance, and level of investment in innovation), as well as the characteristics of the director (sex, age, level of education, degree of autonomy for CSR-related decision-making, motivations, and obstacles).

In relation to these categorical independent variables (size, age, category, type of contract, financial performance, level of investment in innovation; and the sex, age and level of education of the director), it was necessary to convert these to fictitious variables. Whereas for the case of the motivations and obstacles, two PCA were applied whose results are shown in the previous section.

The multiple linear regression for ECA market/competitiveness (Table 8), indicates, according to the coefficient of determination, that $51.36 \%$ of the variance of the dependent variable can be explained by the independent variables under consideration. In other words, if we were to randomly choose a hotel about which we have no information, there will be a certain level of uncertainty (variance) regarding the degree of ECA market/competitiveness application possible; in contrast, if there is information available regarding the independent variables thanks to the present linear regression model, it would be possible to predict and therefore reduce uncertainty by $51.36 \%$. 
Table 8. Final multiple linear regression (only significant variables): ECA market/competitiveness.

\begin{tabular}{ccccccc}
\hline Variable & Beta Coefficient & Standard Error & Student's T & Partial Correlation & Squares & Variance Explained \\
\hline CSR decision capacity & $0.296^{* *}$ & 0.124 & 2.398 & 0.171 & 8.392 \\
Less than 10 Years & $-0.378^{*}$ & 0.208 & -1.816 & -0.130 & 6.194 & 0.038 \\
10 to 20 Years & $-0.450^{* *}$ & 0.223 & -2.020 & -0.145 & 2.965 & 0.028 \\
Bad investment & $-0.665^{* *}$ & 0.279 & -2.380 & -0.170 & 11.436 & 0.014 \\
Regular investment & $-0.770^{* * *}$ & 0.228 & -3.381 & -0.238 & 4.098 & 0.052 \\
Motivations & $0.208^{* * *}$ & 0.060 & 3.496 & 0.245 & 31.749 & 0.019 \\
A woman as a & $0.320^{* * *}$ & 0.123 & 2.610 & 0.186 & 6.580 & 0.030 \\
manager & $-0.236^{* * *}$ & 0.077 & -3.081 & -0.218 & 28.416 \\
Obstacles & & 0.130 & 0.130 \\
\hline
\end{tabular}

Multiple correlation coefficient $=0.717$; coefficient of determination $\left(R^{2}\right)=0.514 R^{2}$ adjusted $=0.445$; alpha regression coefficient $=-0.718$. Level of significance: $1 \%\left({ }^{* *}\right) ; 5 \%\left({ }^{* *}\right) ; 10 \%\left({ }^{*}\right)$.

The multiple linear regression for ECA strategy CSR (Table 9) establishes according to the coefficient of determination that $57.17 \%$ of the variance of the dependent variable may be explained by the independent variables under consideration. In other words, if we were to randomly choose a hotel about which we have no information, there will be a certain level of uncertainty (variance) regarding the degree of ECA strategy CSR application possible; in contrast, if there is information available regarding the independent variables thanks to the present linear regression model, it would be possible to predict and therefore reduce uncertainty by $57.17 \%$.

Table 9. Final multiple linear regression (only significant variables): ECA strategy CSR.

\begin{tabular}{|c|c|c|c|c|c|c|}
\hline Variable & Beta Coefficient & Standard Error & Student's T & Partial Correlation & Squares & Variance Explained \\
\hline Franchise & $1.284 * *$ & 0.568 & 2.261 & 0.162 & 24.527 & 0.112 \\
\hline Less than 10 years & $-0.343 *$ & 0.195 & -1.758 & -0.126 & 0.453 & 0.002 \\
\hline 21 to 40 years & $-0.649^{* * *}$ & 0.209 & -3.102 & -0.219 & 4.911 & 0.022 \\
\hline $\begin{array}{c}\text { A woman as a } \\
\text { manager }\end{array}$ & $0.307^{* * *}$ & 0.115 & 2.670 & 0.190 & 3.602 & 0.016 \\
\hline Obstacles & $-0.283^{* * *}$ & 0.072 & -3.932 & -0.274 & 71.051 & 0.324 \\
\hline 10 to 50 employees & $-0.594 *$ & 0.316 & -1.879 & -0.135 & 2.315 & 0.011 \\
\hline 51 to 200 employees & $-0.662 * *$ & 0.301 & -2.198 & -0.157 & 1.504 & 0.007 \\
\hline
\end{tabular}

Multiple correlation coefficient $=0.756$; coefficient of determination $\left(R^{2}\right)=0.572$. $R^{2}$ adjusted $=0.512$; alpha regression coefficient $=-1.211$. Level of significance: $1 \%\left(^{* * *}\right) ; 5 \%\left(^{* *}\right) ; 10 \%\left(^{*}\right)$.

The multiple linear regression for SOA work conditions and respect for the local community (Table 10) shows that according to the coefficient of determination, $57.64 \%$ of the variance of the dependent variable can be explained by the independent variables under consideration. In other words, if we were to randomly choose a hotel about which we have no information, there will be a certain level of uncertainty (variance) regarding the degree of SOA work conditions and respect for the local community application possible; in contrast, if there is information available regarding the independent variables thanks to the present linear regression model, it would be possible to predict and therefore reduce uncertainty by $57.64 \%$.

The multiple linear regression for SOA policy, social action and disability plan (Table 11) shows that, according to the coefficient of determination, $62.96 \%$ of the variance of the dependent variable may be explained by the independent variables under consideration. In other words, if we were to randomly choose a hotel about which we have no information, there will be a certain level of uncertainty (variance) regarding the degree of SOA policy, social action and disability plan application possible; in contrast, if there is information available regarding the independent variables thanks to the present linear regression model, it would be possible to predict and therefore reduce uncertainty by $62.96 \%$. 
Table 10. Final multiple linear regression (only significant variables): SOA work conditions and respect for the local community.

\begin{tabular}{|c|c|c|c|c|c|c|}
\hline Variable & Beta Coefficient & Standard Error & Student's T & Partial Correlation & Squares & Variance Explained \\
\hline 2-Star hotel & $-0.610 * *$ & 0.256 & -2.385 & -0.170 & 0.878 & 0.004 \\
\hline 5-Star hotel & 0.513 * & 0.287 & 1.785 & 0.128 & 7.516 & 0.034 \\
\hline Bad financial situation & $-0.832 * *$ & 0.327 & -2.546 & -0.181 & 0.662 & 0.003 \\
\hline $\begin{array}{l}\text { Regular financial } \\
\text { situation }\end{array}$ & $-0.992^{* * *}$ & 0.288 & -3.452 & 0.242 & 1.115 & 0.005 \\
\hline Less than 10 years & $-0.447^{* *}$ & 0.194 & -2.304 & -0.164 & 4.646 & 0.021 \\
\hline 10 to 20 years & $-0.678^{* * *}$ & 0.208 & -3.262 & -0.230 & 8.715 & 0.040 \\
\hline Bad investment & $-0.773^{* * *}$ & 0.261 & -2.964 & -0.210 & 4.452 & 0.020 \\
\hline Regular investment & $-0.623^{* * *}$ & 0.213 & -2.930 & -0.207 & 3.717 & 0.017 \\
\hline Motivations & $0.178^{* * *}$ & 0.056 & 3.200 & 0.226 & 9.511 & 0.043 \\
\hline Obstacles & $-0.407^{* * *}$ & 0.072 & -5.688 & -0.381 & 71.538 & 0.327 \\
\hline Postgraduate studies & 0.611 * & 0.322 & 1.897 & 0.136 & 0.866 & 0.004 \\
\hline $\begin{array}{c}\text { Less than } 10 \\
\text { employees }\end{array}$ & -0.561 * & 0.328 & -1.710 & -0.123 & 2.875 & 0.013 \\
\hline
\end{tabular}

Multiple correlation coefficient $=0.759$; coefficient of determination $\left(R^{2}\right)=0.576 . R^{2}$ adjusted $=0.517$; alpha regression coefficient $=-0.676$. Level of significance: $1 \%\left({ }^{* *}\right) ; 5 \%\left({ }^{* *}\right) ; 10 \%\left({ }^{*}\right)$.

Table 11. Final multiple linear regression (only significant variables): SOA policy, social action, and disability plan.

\begin{tabular}{|c|c|c|c|c|c|c|}
\hline Variable & Beta Coefficient & Standard Error & Student's T & Partial Correlation & Squares & Variance Explained \\
\hline 2-Star hotel & $-0.395 *$ & 0.239 & -1.654 & -0.119 & 1.454 & 0.007 \\
\hline 5-Star hotel & $0.570 * *$ & 0.269 & 2.122 & 0.152 & 5.794 & 0.027 \\
\hline Franchise & 0.895 * & 0.528 & 1.695 & 0.122 & 4.336 & 0.020 \\
\hline $\begin{array}{l}\text { A woman as a } \\
\text { manager }\end{array}$ & $0.279^{* * *}$ & 0.107 & 2.607 & 0.185 & 6.731 & 0.031 \\
\hline $\begin{array}{l}\text { Less than } 10 \\
\text { employees }\end{array}$ & $-1.310^{* * *}$ & 0.307 & -4.271 & -0.295 & 41.639 & 0.190 \\
\hline 10 to 50 employees & $-0.994^{* * *}$ & 0.294 & -3.383 & -0.238 & 28.821 & 0.132 \\
\hline 51 to 200 employees & $-0.500 *$ & 0.280 & -1.785 & -0.128 & 1.161 & 0.005 \\
\hline
\end{tabular}

Multiple correlation coefficient $=0.794$; coefficient of determination $\left(R^{2}\right)=0.630 . R^{2}$ adjusted $=0.578$; alpha regression coefficient $=-0.208$. Level of significance: $1 \%\left({ }^{* * *}\right) ; 5 \%\left({ }^{* *}\right) ; 10 \%\left({ }^{*}\right)$.

Finally, the multiple linear regression for ENA environmental activities (Table 12) shows that, according to the coefficient of determination, $66.75 \%$ of the variance of the dependent variable may be explained by the independent variables under consideration. In other words, if we were to randomly choose a hotel about which we have no information, there will be a certain level of uncertainty (variance) regarding the degree of ENA environmental activities application possible; in contrast, if there is information available regarding the independent variables thanks to the present linear regression model, it would be possible to predict and therefore reduce uncertainty by $66.75 \%$.

Table 12. Final multiple linear regression (only significant variables): ENA environmental activities.

\begin{tabular}{|c|c|c|c|c|c|c|}
\hline Variable & Beta Coefficient & Standard Error & Student's T & Partial Correlation & Squares & Variance Explained \\
\hline Bad financial situation & $-0.666 * *$ & 0.290 & -2.300 & -0.164 & 0.065 & 0.000 \\
\hline Bad investment & $-0.811^{* * * *}$ & 0.231 & -3.514 & -0.246 & 15.614 & 0.071 \\
\hline Regular investment & $-0.548^{* * *}$ & 0.188 & -2.909 & -0.206 & 23.632 & 0.108 \\
\hline $\begin{array}{l}\text { A woman as a } \\
\text { manager }\end{array}$ & 0.171 * & 0.101 & 1.683 & 0.121 & 0.247 & 0.001 \\
\hline Obstacles & $-0.285^{* * *}$ & 0.063 & -4.487 & -0.309 & 87.914 & 0.401 \\
\hline Postgraduate studies & $0.653^{* *}$ & 0.285 & 2.289 & 0.163 & 5.378 & 0.025 \\
\hline
\end{tabular}

Multiple correlation coefficient $=0.817$; coefficient of determination $\left(R^{2}\right)=0.668 ; R^{2}$ adjusted $=0.621$; alpha regression coefficient $=-0.563$. Level of significance: $1 \%\left({ }^{* * *}\right) ; 5 \%\left(^{* *}\right) ; 10 \%\left(^{*}\right)$.

\section{Discussion}

Based on the analysis of the results above, it has been possible to identify the factors that determine the degree of CSR application in hotels of the Colombian Caribbean from their economic (ECA market/competitiveness and ECA strategy CSR), social (SOA work conditions and respect for the local community and SOA policy, social action, and disability plan) and environmental (ENA environmental activities) dimensions. Below is a detailed explanation of this. 
The degree of ECA market/competitiveness application increases along with the motivations and the director's degree of autonomy for CSR-related decision-making and when the director is a woman. On the other hand, it diminishes as the level of investment in innovation (in the medium or bad categories) and the age of the hotel (in its categories of 10-20 years in operation and less than 10 in operation) decrease. The degree of ECA strategy CSR application increases when the director is a woman and the hotel is a franchise; in contrast, it reduces as the obstacles perceived by the director, and hotel age (in its categories of 21-40 years in operation and less than 10 in operation) and size (in its categories of 51-200 and 10-50 employees) increase.

The degree of SOA work conditions and respect for the local community application increases as the director's motivations increase, especially if he or she holds a postgraduate degree. It also increases along with the category of the hotel (concretely a five-star category). In contrast, it reduces as the director's obstacles increase along with the hotel's financial performance (in the medium or bad categories), age (in its categories of 10-20 years in operation and less than 10 in operation), level of investment in innovation (in the medium or bad categories), category (concretely a two-star category), and size (in its category of less than 10 employees) decrease. Similarly, the degree of SOA policy, social action, and disability plan application increases if the director is a woman, if the hotel goes up in terms of its category (concretely a five-star category), and is a franchise. On the other hand, it reduces as the hotel size (in its category of less than 10 employees, from 10-20, and from 51-200), level of investment in innovation (in its category of bad), and category (concretely a two-star category) decrease.

Finally, the degree of ENA environmental activities application increases as the director's level of education increases and if the director has a postgraduate degree and is a woman respectively. On the other hand, it reduces as the director's obstacles increase along with the hotel's level of investment in innovation (in the medium or bad categories) and financial performance (in the bad category) decrease.

In general, it can be said that the degree of application of CSR activities is positively affected as the size of the hotel increases, the longer it has been in operation, the higher its category, if it is a franchise, with good financial performance, and a good level of investment in innovation, as well as if the director is a woman with a postgraduate degree, autonomous in CSR-related decision-making, with motivation derived from her values and management style, improved competitiveness and hotel image, and stakeholder pressure. In contrast, obstacles deriving from attitude and management style, lack of knowledge, and the absence of resources (financial, time and human) and of government support, have a negative influence on the degree of CSR application. Therefore, H1 hypothesis and H2 hypothesis are accepted.

As a contribution to the validation and contextualization of these results, carrying out specific analyses for each variable, the results that include hotel size, coincide with those found in the works of $[40,41,70]$; those related to the age of the hotel coincide with the results of [41,42,57]; those regarding the variables sex, age, and educational level of the director, with the studies conducted by $[41,43-54,57]$.

It is undisputable then that the findings in relation to the determinants of CSR application are a tool of practical and useful information for hotel directors in the Colombian Caribbean to help them improve the levels of CSR application.

\section{Conclusions}

The CSR concept is being adopted by many leaders in private sector industries involved in, for example, the extraction of natural resources, manufacture, textiles and forestry [71]. The concept is also important to the tourism and hospitality industries [36], because it makes a significant contribution to attract and retain valuable employees [72]; however, although the literature on CSR in tourism and hospitality has been increasing especially in the last five years [16], the review carried out has revealed the scarcity of works in comparison with other sectors, coinciding with the arguments of $[12,16]$ in the tourism sector in general, and [13] in the hotel industry in particular.

In this respect, the purpose of this study has been to understand CSR, from the perspective of its application to tourism, concretely to the hotel industry, in a Latin American countries such as Colombia, 
specifically in its Caribbean region, considered one of the country's most important tourist areas, with particular natural, geographic, historical, and cultural characteristics making it a region with great potential for the development of tourism in Latin America.

Thus this study has focused on the hotel industry in the Colombian Caribbean, establishing the existence of factors that determine the degree of CSR application, related to some hotel's characteristics like size, age, category, type of contract, financial performance, and level of investment in innovation; as well as several director's characteristics, like sex, age, level of education, degree of autonomy for CSR-related decision-making, and perceived motivations and obstacles; and something that complements in a good way this, is the list of thirty proposed activities for the economic, environmental, and social issues of the hotels (ECA, SOA, and ENA), an important contributions of this work. It is the first study that makes an integral analysis with all these cited variables.

There is no doubt about the important managerial implications of the conclusions of this study on hotels in the Colombian Caribbean. Managers can now have access to valuable information to help their decision-making in order to improve the levels of the sector's CSR application and therefore promote actions that contribute, more effectively, to a more responsible and sustainable development of responsible and sustainable tourism in the area.

These findings are very important, especially today when CRS is identified as an ideal way to position a company in the market [73] and even more so where the creation of social value occupies such a relevant position, as that of the creation of a company's economic value [74]; this is reinforced by [75] arguing that corporate social action creates economic value through strategic social planning and strategic social positioning.

In addition, within the tourism and hotel industry, it is important to mention the impact of the application of CSR on an internal stakeholder that is fundamental to the company: the employees. Concretely, social (philanthropy) and economic CSR activities have a positive effect on their quality of life at work, their satisfaction and, therefore, their quality of life in general [76]. Employee perception of CSR has a significant and positive affect on their commitment to the job that, in turn, has a positive influence on their innovative behavior and their intention to stay at the company [77]. This undoubtedly provides greater value to the results shown in this study, as they become managerial implications that must be taken into account by the hotel directors in the study.

On the other hand, there is no doubt that the traditional distinction between systems of corporate governance focusing on the shareholder and those that focus on stakeholders is important for the CSR strategy [78] and, in this respect, the growing pressure of external stakeholders, including governments, clients, environmental groups and activists, make the companies implement more and more CSR initiatives [79]. It is clear then that CSR practices are becoming more common due to a variety of social, environmental, and economic pressures [80] and this issue has been progressing due to the global changes in society and the way that CSR is perceived in relation to its role in the promotion and support of sustainable development [81]. Thus, research in CSR also has to consider the relevance and application of CSR and its relationship with stakeholders external to the organization; for example, in the case of costumers many tourism corporate responsibility programs require the support of guests, therefore it is necessary to design strategies to encourage guests' adoption of responsible behaviors [82].

With this in mind, it is clear that this work contributes to this type of study, as the economic, social, and environmental activities used to measure the degree of CSR application of the companies in the study consider the stakeholders, which, in other words, is an additional managerial implication. However, to expand and improve these implications, it is recommended that future researchers take into consideration the type of corporate governance and the risk appetite of the decision-making body of the company, because it could be interesting to know the type of relationship of these variables with CSR practices in the hospitality industry.

Finally, it is important to mention that studies on CSR (including this one) have traditionally focused on the responsibility of the company as an independent entity whose point of view includes responsibility towards the community and the environment in which it operates. It tends, however, 
to ignore the collective influence of socially responsible behaviors that take place between interrelated entities that see the tourist destination as a whole [83]. Precisely, the most important limitation of this study is that it doesn't take into account all the entities or stakeholders of the destination, therefore social responsibility practices could not be established in a systematic and integral way to all actors.

Therefore, future research should consider not only the application of social responsibility in the corporate sector, but also in all stakeholders, organisms, and institutions (public and private), as well as non-governmental organizations and civil society that directly or indirectly have some kind of relationship with the whole tourism system. This, we believe, is the only way to make a real contribution to the sustainable development of the destination.

Author Contributions: This paper is the result of the joint work by all authors. D.D.P.M. designed and performed the research. D.D.P.M. and J.R.C. analyzed the data's research. D.D.P.M., J.A.-O. and J.R.C. wrote the paper. All authors read and approved the final manuscript.

Funding: This research received no external funding.

Conflicts of Interest: The authors declare no conflict of interest.

\section{References}

1. Nyahunzvi, D.K. CSR reporting among Zimbabwe's hotel groups: A content analysis. Int. J. Contemp. Hosp. Manag. 2013, 25, 595-613. [CrossRef]

2. KPMG International. The KPMG Survey of Corporate Responsibility Reporting; KPMG International: Zurich, Switzerland, 2017.

3. Bass, A.; Milosevec, I. The ethnographic method in CSR research: The role and importance of methodological fit. Bus. Soc. 2018, 57, 174-215. [CrossRef]

4. Madorrán, C.; García, T. Corporate social responsibility and financial performance: The spanish case. RAE Rev. Adm. Empresas 2016, 56, 20-28. [CrossRef]

5. Carroll, A.B. A three-dimensional conceptual model of corporate performance. Acad. Manag. Rev. 1979, 4, 497-505. [CrossRef]

6. Lee, C.K.; Kim, J.; Kim, J.S. Impact of a gaming company's CSR on residents' perceived benefits, quality of life, and support. Tour. Manag. 2018, 64, 281-290. [CrossRef]

7. Bondy, K.; Moon, J.; Matten, D. An institution of corporate social responsibility (CSR) in multi-national corporations (MNCs): Form and implications. J. Bus. Ethics 2012, 114, 281-299. [CrossRef]

8. De la Cuesta, M.; Valor, M.; Sanmartín, M.; Botija, M. La Responsabilidad Social Corporativa: Una Aplicación a España; UNED: Madrid, España, 2002.

9. Yepes, G.; Peña, W.; Sánchez, L. Responsabilidad Social Empresarial. Fundamentos y Aplicación en Las Organizaciones de Hoy; Universidad Externado de Colombia: Bogotá, Colombia, 2007.

10. Guédez, V. Responsabilidad Social Empresarial. Visiones Complementarias. Hacia un Modelaje Social; Cámara Venezolano Americana de Comercio e Industria-Venamcham: Caracas, Venezuela, 2010.

11. Kim, H.; Woo, E.; Uysal, M.; Kwon, N. The effects of corporate social responsibility (CSR) on employee well-being in the hospitality industry. Int. J. Contemp. Hosp. Manag. 2018, 30, 1584-1600. [CrossRef]

12. Holcomb, J.L.; Upchurch, R.S.; Okumus, F. Corporate social responsibility: What are the top hotel companies reporting? Int. J. Contemp. Hosp. Manag. 2007, 19, 461-475. [CrossRef]

13. Serra, A.; Peña, D.; Ramón, J.; Martorell, O. Progress in research on CSR and the hotel industry (2006-2015). Cornell Hosp. Q. 2018, 59, 15-38. [CrossRef]

14. Ehsan, S.; Nazir, M.S.; Nurunnabi, M.; Khan, Q.R.; Tahir, S.; Ahmed, I. A Multimethod Approach to Assess and Measure Corporate Social Responsibility Disclosure and Practices in a Developing Economy. Sustainability 2018, 10, 2955. [CrossRef]

15. Bohdanowicz, P. Environmental awareness and initiatives in the swedish and polish hotel industries-survey results. Int. J. Hosp. Manag. 2006, 25, 662-682. [CrossRef]

16. Font, X.; Lynes, J. Corporate social responsibility in tourism and hospitality. J. Sustain. Tour. 2018, 26, 1027-1042. [CrossRef]

17. Horng, J.-S.; Hsu, H.; Tsai, C.-Y. An assessment model of corporate social responsibility practice in the tourism industry. J. Sustain. Tour. 2018, 26, 1085-1104. [CrossRef] 
18. Carroll, A.B. The pyramid of corporate social responsibility: Toward the moral management of organizational stakeholders. Bus. Horiz. 1991, 34, 39-48. [CrossRef]

19. Wood, D.J. Corporate social performance revisites. Acad. Manag. Rev. 1991, 14, 691-718. [CrossRef]

20. Lantos, G. The boundaries of strategic corporate social responsibility. J. Consum. Mark. 2001, 18, 595-630. [CrossRef]

21. Van Marrewijk, M. Concepts and definitions of CSR and corporate sustainability: Between agency and communion. J. Bus. Ethics 2003, 44, 95-105. [CrossRef]

22. Garriga, E.; Melé, D. Corporate Social Responsibility Theories: Mapping the Territory. J. Bus. Ethics 2004, 53, 51-71. [CrossRef]

23. Argandoña, A.; Hoivik, H. Corporate Social Responsibility: One Size Does Not Fit All. Collecting Evidence from Europe. J. Bus. Ethics 2009, 89, 221-234. [CrossRef]

24. Freeman, R.E.; Reed, D.L. Stockholders and Stakeholders: A new perspective on Corporate Governance. Calif. Manag. Rev. 1983, 25, 88-106. [CrossRef]

25. Kaku, R. The path of Kyosei. Harv. Bus. Rev. 1997, 75, 55-66. [PubMed]

26. Annan, K. UN Global Compact; UN Press Release SG/SM/6881; World Economic Forum: Davos, Switzerland, 1999.

27. Chomali, F.; Majluf, N. Ética y Responsabilidad Social en La Empresa; Aguilar Chilena de Ediciones S.A.: Santiago de Chile, Chile, 2007.

28. General Assembly of the United Nations. Available online: http://www.un.org/es/ga/president/65/issues/ sustdev.shtml (accessed on 10 July 2019).

29. Godos-Díez, J.; Fernández-Gago, R.; Martínez-Campillo, A. How important are CEOs to CSR practices? An analysis of the mediating effect of the perceived role of ethics and social responsibility. J. Bus. Ethics 2011, 98, 531-548. [CrossRef]

30. United Nations-UN. Global Code of Ethics for Tourism; A/ RES/56/212; United Nations: New York, NY, USA, 2001.

31. United Nations World Tourism Organization-UNWTO. Global Code of Ethics for Tourism; United Nations World Tourism Organization: Santiago de Chile, Chile, 1999.

32. Bohdanowicz, P. A case study of Hilton environmental reporting as a tool of corporate social responsibility. Tour. Rev. Int. 2007, 11, 115-131. [CrossRef]

33. Sheldon, P.; Park, S. An Exploratory Study of Corporate Social Responsibility in the U.S. Travel Industry. J. Travel Res. 2011, 50, 392-407. [CrossRef]

34. Coles, T.; Fenclova, E.; Dinan, C. Tourism and corporate social responsibility: A critical review and research agenda. Tourism Management Perspectives 2013, 6, 122-141. [CrossRef]

35. Camilleri, M.A. Advancing the sustainable tourism agenda through strategic CSR perspectives. Tour. Plan. Dev. 2014, 11, 42-56. [CrossRef]

36. Farrington, T.; Curran, R.; Gori, K.; O'Gorman, K.; Queenan, C. Corporate social responsibility: Reviewed, rated, revised. Int. J. Contemp. Hosp. Manag. 2017, 29, 30-47. [CrossRef]

37. Peña, D.; Guevara, A.; Fraiz, J. La investigación de la Responsabilidad Social Empresarial en el sector hotelero. Análisis y revisión de la literatura científica. Tur. Soc. 2016, XVIII, 137-158. [CrossRef]

38. Bondy, K. The paradox of power in CSR: A case study on implementation. J. Bus. Ethics 2008, 82, $307-323$. [CrossRef]

39. Vives, A.; Corral, A.; Isusi, I. Responsabilidad Social de La Empresa en Las PyMEs de Latinoamérica; Banco Interamericano de Desarrollo (BID) e ikei research and consultancy: Washington, DC, USA, 2005.

40. Correa, J. Evolución histórica de los conceptos de Responsabilidad Social Empresarial y balance social. Semest. Econ. 2007, 10, 87-102.

41. Garay, L.; Font, X. Doing good to do well? Corporate social responsibility reasons, practices and impacts in small and medium accommodation enterprises. Int. J. Hosp. Manag. 2012, 31, 329-337. [CrossRef]

42. Shrivastava, P. The role of corporations in achieving ecological sustainability. Acad. Manag. Rev. 1995, 20, 936-960. [CrossRef]

43. Kelley, L.; Whatley, A.; Worthley, R. Assessing the effects of culture on managerial attitudes: A three-culture test. J. Int. Bus. Stud. 1987, 18, 17-31. [CrossRef]

44. Ibrahim, N.A.; Angelidis, J.P. Effects of board members' gender on level of involvement in strategic management and corporate social responsiveness orientation. Proc. Northeast Decis. Sci. Inst. 1991, 208, 210. 
45. Ibrahim, N.A.; Angelidis, J.P. Effect of board members' gender on corporate social responsiveness orientation. J. Appl. Bus. Res. 1994, 10, 35-40. [CrossRef]

46. Ibrahim, N.A.; Angelidis, J.P. The corporate social responsiveness orientation of board members: Are there differences between inside and outside directors? J. Bus. Ethics 1995, 14, 405-410. [CrossRef]

47. Angelidis, J.P.; Ibrahim, N.A. Practical implications of educational background on future corporate exceutives' social responsibility orientation. Teach. Bus. Ethics 2002, 6, 117-126. [CrossRef]

48. Ibrahim, N.A.; Howard, D.P.; Angelidis, J.P. Board members in the service industry: An empirical examination of the relationship between corporate social responsibility orientation and directorial type. J. Bus. Ethics 2003, 47, 393-401. [CrossRef]

49. Hemingway, C.A.; Maclagan, P.W. Managers' personal values as drivers of corporate social responsibility. J. Bus. Ethics 2004, 50, 33-44. [CrossRef]

50. Deng, J.; Walker, G.J.; Swinnerton, G. A comparison of environmental values and attitudes between chinese in Canada and anglo-canadians. Environ. Behav. 2006, 38, 22-47. [CrossRef]

51. Dief, M.E.; Font, X. Determinants of environmental management in the Red Sea Hotels: Personal and organizational values and contextual variables. J. Hosp. Tour. Res. 2010, 36, 115-137. [CrossRef]

52. Petts, J. Environmental responsiveness, individuals and organizational learning: SME experience. J. Environ. Plan. Manag. 1998, 41, 711-730. [CrossRef]

53. Rivera, J.; de Leon, P. Chief executive officers and voluntary environmental performance: Costa Rica's certification for sustainable tourism. Policy Sci. 2005, 38, 107-127. [CrossRef]

54. Ewert, A.; Baker, D. Standing for where you sit: An exploratory analysis of the relationship between academic major and environmental beliefs. Environ. Behav. 2001, 33, 687-707. [CrossRef]

55. Kusyk, S.; Lozano, J.M. SME social performance: A four-cell typology of key drivers and barriers on social issues and their implications for stakeholder theory. Corp. Gov. 2007, 7, 502-515. [CrossRef]

56. Huimin, G.; Ryan, C. Ethics and corporate social responsibility-An analysis of the views of Chinese hotel managers. Int. J. Hosp. Manag. 2011, 30, 875-885. [CrossRef]

57. Peña, D.; Serra, A. Responsabilidad Social Empresarial en el sector turístico. Estudio de caso en empresa de alojamiento de la ciudad de Santa Marta, Colombia. Estud. Perspect. Tur. 2012, 21, 1456-1480.

58. Peña, D.; Serra, A. La práctica de la responsabilidad social empresarial. Estudio de caso en el sector turístico. Innovar 2013, 23, 101-114.

59. Alwyn, L.; Kiyoteru, T. Globalization and Commitment in Corporate Social Responsibility: Cross-National Analyses of Institutional and Political-Economy Effects. Am. Sociol. Rev. 2012, 77, 69-98. [CrossRef]

60. Casado, F.; Roser, I. La RSE de La Empresa Española en América Latina; Documento de Trabajo No 34; Fundación Carolina-CeAlCI: Madrid, España, 2009.

61. Heincke, M. La Responsabilidad Social Empresarial: ¿Una herramienta para el desarrollo local sostenible en Colombia? Rev. Opera 2005, 5, 55-74.

62. World Travel and Tourism Council-WTTC. Corporate Social Leadership in Travel E Tourism; World Travel and Tourism Council: London, UK, 2002.

63. Henderson, J. Corporate social responsibility and tourism: Hotel companies in Phuket, Thailand, after the Indian Ocean tsunami. Int. J. Hosp. Manag. 2007, 26, 228-239. [CrossRef]

64. Bohdanowicz, P.; Zientara, P. Hotel companies' contribution to improving the quality of life of local communities and the well-being of their employees. Tour. Hosp. Res. 2009, 9, 147-158. [CrossRef]

65. De Grosbois, D. Corporate social responsibility reporting by the global hotel industry: Commitment, initiatives and performance. Int. J. Hosp. Manag. 2012, 31, 896-905. [CrossRef]

66. Levy, S.E.; Park, S.-Y. An Analysis of CSR Activities in the Lodging Industry. J. Hosp. Tour. Manag. 2011, 18, 147-154. [CrossRef]

67. Tsai, W.; Hsu, L.; Chen, C.; Lin, W.; Chen, S. An integrated approach for selecting corporate social responsibility programs and costs evaluation in the international tourist hotel. Int. J. Hosp. Manag. 2010, 29, 385-396. [CrossRef]

68. Font, X.; Walmsley, A.; Cogotti, S.; McCombes, L.; Häusler, N. Corporate social responsibility: The disclosure-performance gap. Tour. Manag. 2012, 33, 1544-1553. [CrossRef]

69. Santesmases, M. DYANE: Diseño y Análisis de Encuestas en Investigación Social y de Mercados, 4th ed.; Pirámide: Madrid, España, 2009. 
70. Gutiérrez, L.; Avella, L.; Villar, R. Aportes y Desafíos de La Responsabilidad Social Empresarial en Colombia; Universidad de los Andes-Edisoma Ediciones Especiales: Bogotá, Colombia, 2006.

71. Dodds, R.; Rogers, T. CSR among canadian mass tour operators: Good awareness but little action. Int. J. Contemp. Hosp. Manag. 2010, 22, 221-244. [CrossRef]

72. Gligor-Cimpoieru, D.C.; Munteanu, V.P.; Nițu-Antonie, R.D.; Schneider, A.; Preda, G. Perceptions of Future Employees toward CSR Environmental Practices in Tourism. Sustainability 2017, 9, 1631. [CrossRef]

73. Dopico-Parada, A.; Rodríguez-Daponte, R.; González-Vázquez, E. Valoración de la RSC por el consumidor y medición de su efecto sobre las compras. RAE Rev. Adm. Empresas 2014, 54, 39-52. [CrossRef]

74. Sierra-García, L.; García-Benau, M.; Zorio, A. Credibilidad en latinoamérica del informe de responsabilidad social corporativa. RAE Rev. Adm. Empresas 2014, 54, 28-34. [CrossRef]

75. Husted, B.; Bruce, D.; Kock, N. Value creation through social strategy. Bus. Soc. 2015, 54, 147-186. [CrossRef]

76. Kim, B.; Lee, S.; Kang, K.H. The moderating role of CEO narcissism on the relationship between uncertainty avoidance and CSR. Tour. Manag. 2018, 67, 203-213. [CrossRef]

77. Park, S.-Y.; Lee, C.-K.; Kim, H. The influence of corporate social responsibility on travel company employees. Int. J. Contemp. Hosp. Manag. 2018, 30, 178-196. [CrossRef]

78. Ayuso, S.; Rodríguez, M.; García-Castro, R.; Ariño, M. Maximizing stakeholders' interests an empirical analysis of the stakeholder approach to corporate governance. Bus. Soc. 2014, 53, 414-439. [CrossRef]

79. $\mathrm{Xu}, \mathrm{Y}$. Understanding CSR from the perspective of chinese diners: The case of McDonald's. Int. J. Contemp. Hosp. Manag. 2014, 26, 1002-1020. [CrossRef]

80. Li, K.; Khalili, N.R.; Cheng, W. Corporate Social Responsibility Practices in China: Trends, Context, and Impact on Company Performance. Sustainability 2019, 11, 354. [CrossRef]

81. Andersen, I.M.; Blichfeldt, B.S.; Liburd, J. Sustainability in coastal tourism development: An example from Denmark. Curr. Issues Tour. 2017, 21, 1329-1336. [CrossRef]

82. Moscardo, G.; Hughes, K. All aboard! Strategies for engaging guests in corporate responsibility programmes. J. Sustain. Tour. 2018, 26, 1257-1272. [CrossRef]

83. Su, L.; Swanson, S.R. The effect of destination social responsibility on tourist environmentally responsible behavior: Compared analysis of first time and repeat tourists. Tour. Manag. 2017, 60, 308-321. [CrossRef]

(C) 2019 by the authors. Licensee MDPI, Basel, Switzerland. This article is an open access article distributed under the terms and conditions of the Creative Commons Attribution (CC BY) license (http://creativecommons.org/licenses/by/4.0/). 